\title{
Identifikasi Hijauan Makanan Ternak (HMT) Lokal Mendukung Produktivitas Sapi Potong di Sulawesi Selatan
}

\author{
(The Identification of Local Forages to Support the Productivity \\ of Beef Cattle in South Sulawesi) \\ Saking $\mathrm{N}^{1}$, Qomariyah $\mathrm{N}^{2}$ \\ ${ }^{1}$ UPTD Pembibitan Ternak-Hijauan Pakan Ternak, Dinas Peternakan dan Kesehatan Hewan \\ Provinsi Sulawesi Selatan, Jl. Veteran Selatan No. 234, Makassar \\ ${ }^{2}$ Balai Pengkajian Teknologi Pertanian Sulawesi Selatan, Jl. Perintis Kemerdekaan km 18, Makassar \\ novia_joyo@yahoo.com
}

\begin{abstract}
One of the ways to overcome the shortage of forage mainly during the dry season is to utilize and identified the abundant availability of local forage. This study aims to identify local forage potential to be developed as a livestock feed to support the productivity of beef cattle in South Sulawesi. This research was conducted in UPTD Nurseries Pucak HMT Village, District Tompobulu, Maros, South Sulawesi Province in August 2016. The local forage identified were Kangkungan Darat, Kiti-kiti Balanda and Jonga-jonga. The result showed that crude protein and crude fiber content of Kangkungan Darat, Kiti-kiti Balanda and Jonga-jonga were 21.36 and 12.81\%; 24.55 and 15.62\%; 22.63 and 9.81\%, respectively. While content of Hydro Cyanic Acid $(\mathrm{HCN})$ and tannin of these local forage were $15.907 \mathrm{ppm}$ and $0.063 \% ; 18.830 \mathrm{ppm}$ and $0.389 \%$; $18.917 \mathrm{ppm}$ and $0.169 \%$, respectively. Based on these crude protein content, crude fiber, HCN and tannin that were $>20 \%,<18 \%, 15-19 \%$ and $0.063-0.389 \%$, respectively, it can be concluded that Kangkungan Darat, Kiti-kiti Balanda and Jonga-jonga can be used as an alternative of ruminant feed. Feeding livestock should be combined with consentrate to improve the palatability of feed.
\end{abstract}

Key Words: Local Forage, Productivity, Beef Cattle

\begin{abstract}
ABSTRAK
Salah satu cara untuk mengatasi kekurangan hijauan makanan ternak terutama pada musim kemarau adalah dengan mengidentifikasi dan memanfaatkan hijauan lokal yang ketersediaannya melimpah. Penelitian ini bertujuan untuk mengidentifikasi hijauan pakan lokal yang potensial untuk dikembangkan sebagai pakan ternak mendukung pengembangan sapi potong di Sulawesi Selatan. Penelitian dilaksanakan di UPTD Pembibitan HMT Desa Pucak, Kecamatan Tompobulu, Kabupaten Maros, Provinsi Sulawesi Selatan pada bulan Agustus 2016. Jenis hijauan pakan lokal yang diidentifikasi adalah Kangkungan Darat, Kiti-kiti Balanda dan Jonga-jonga. Diperoleh hasil bahwa kandungan protein kasar (PK) dan serat kasar (SK) pada Kangkungan Darat sebesar 21,36 dan 12,81\%, pada Kiti-kiti Balanda 24,55 dan 15,62\%, serta di Jonga-jonga 22,63 dan 9,81\%. Kandungan Hydro Cyanic Acid (HCN) dan tanin pada Kangkungan Darat sebesar 15,907 ppm dan 0,063\%, pada Kiti-kiti Balanda 18,830 ppm dan 0,389\%, serta di Jonga-jonga 18,917 ppm dan $0,169 \%$. Berdasarkan bahwa kandungan PK $>20 \%$, SK $<18 \%$, HCN $15-19 \%$ dan tanin 0,0630,389\%, dapat disimpulkan bahwa Kangkungan Darat, Kiti-kiti Belanda dan Jonga-jonga dapat dijadikan sebagai alternatif pakan ternak. Pemberian pakan ternak harus dikombinasikan dengan pemberian konsentrat untuk meningkatkan palatabilitas pakan.
\end{abstract}

Kata Kunci: Hijauan Lokal, Pengembangan, Sapi Potong 


\section{PENDAHULUAN}

Sumber bahan pakan utama ternak ruminansia adalah hijauan baik berupa rumput, leguminosa maupun limbah pertanian/perkebunan yang digunakan untuk hidup pokok, pertumbuhan, produksi (daging, susu) maupun untuk reproduksi. Menurut Nitis et al. (1992) $70 \%$ dari makanan ternak ruminansia adalah hijauan. Sebagian besar peternak di Indonesia memperoleh hijauan dari kebun/ladang/sawah sendiri, pinggir jalan, pematang sawah, lapangan, tepi hutan maupun sisa hasil pertanian/perkebunan.Sementara itu hijauan yang diperoleh dari penanaman/budidaya secara intensif sangat sedikit. Hal ini dikarenakan semakin berkurangnya lahan-lahan subur atau produktif sebagai penyedia hijauan pakan yang berdampak pada kesulitan peternak dalam penyediaan hijauan pakan bagi ternaknya. Ditambahkan oleh Haryanto (2004) bahwa menurunnya daya dukung sumberdaya alam (pakan) untuk ternak karena konversi lahan pertanian. Menurut Badan Ketahanan Pangan Nasional (2010) sepanjang tahun 2009 telah terjadi alih fungsi lahan pertanian hingga mencapai 110 ribu hektar (ha). Disisi lain sub-sektor peternakan dituntut mencukupi permintaan akan protein hewani yang semakin meningkat, sehingga harus dipacu baik dari segi kuantitas maupun kualitas produksinya. Namun demikian, sub-sektor peternakan dihadapkan pada semakin menyempitnya lahan usaha akibat persaingan yang semakin meningkat baik antar sektor maupun antar sub-sektor dalam penggunaan lahan.

Peternak di Indonesia umumnya dan di Sulawesi Selatan pada khususmya masih menggantungkan hijauan dari alam (rumput/leguminosa lokal) sehingga ketersediaanya tidak kontinu. Pada musim penghujan sangat melimpah, sebaliknya pada musim kemarau sangat minim. Untuk mengatasi hal tersebut, pada umumnya peternak akan mencari beberapa hijauan langka/liar yang melimpah ketersediaanya pada musim kemarau. Beberapa rumput/leguminosa liar yang tumbuh subur pada saat musim kemarau akan menjadi primadona bagi beberapa peternak di Sulawesi Selatan. Tujuan penelitian ini adalah mengidentifikasi hijauan pakan lokal yang potensial untuk dikembangkan sebagai pakan ternak mendukung produktivitas sapi potong di Sulawesi Selatan.

\section{MATERI DAN METODE}

\section{Waktu dan tempat}

Kegiatan penelitian ini dilaksanakan di UPTD Pembibitan HMT di Desa Pucak, Kecamatan Tompobulu, Kabupaten Maros, Provinsi Sulawesi Selatan pada bulan Agustus 2016.

\section{Bahan dan alat}

Adapun alat yang digunakan meliputi timbangan, kamera, oven dan hijauan lokal. Sampel hijauan diperoleh di sekitar UPTD Pembibitan HMT.

\section{Metode}

Metode yang digunakan adalah pengamatan dan pencatatan langsung di lokasi penelitian untuk menentukan jenis hijauan liar yang tumbuh di sekitar UPTD Pembibitan HMT. Semua hijauan yang jumlahnya berlimpah diambil sampel dan difoto lalu dilakukan identifikasi dan klasifikasi dari tanaman hijauan tersebut (phylum, suphylum, classis, ordo, subordo, familia, subfamilia, genus dan species). 
Tahapan dalam pengambilan sampel, diawali dengan mengukur tinggi hijauan yang akan dijadikan sampel dengan menggunakan tongkat ukur, yaitu dari permukaan tanah sampai ujung daun tertinggi rumput. Rumput yang telah diukur, dipotong dengan tinggi pemotongan $5 \mathrm{~cm}$ dari permukaan tanah, kemudian ditimbang berat segar yang dihasilkan. Selanjutnya rumput dikeringkan di dalam oven pada suhu $60^{\circ} \mathrm{C}$ selama 48 jam, kemudian berat bahan keringnya ditimbang untuk selanjutnya dianalisis proksimat untuk mengetahui kandungan nutrisinya. Hijauan yang diperoleh diuji cobakan juga ke ternak untuk mengetahui daya suka ternak/palatabilitas. Data dan informasi yang diperoleh selanjutnya ditampilkan secara deskriptif.

\section{Pengumpulan data}

Data yang dikumpulkan meliputi bentuk dan warna dari akar, batang, daun, dan bunga tanaman, kandungan nutrisi dan antinutrisi hijauan.

\section{HASIL DAN PEMBAHASAN}

\section{Identifikasi jenis hijauan/leguminosa}

Komponen penting dalam peternakan ruminansia adalah penyediaan pakan hijauan yang kontinu dan berkelanjutan. Bagi sebagian besar peternak di Indonesia pemberian pakan hijauan dapat diberikan secara langsung yaitu dengan digembalakan (grazing) maupun tidak langsung/potong-angkut (cut and carry). Pemilihan lahan untuk padang penggembalaan dan lahan penanaman hijauan harus memperhatikan faktor lingkungan karena faktor lingkungan sangat berpengaruh terhadap kualitas dan kuantitas hijauan yang akan diberikan kepada ternak. Pemeliharaan ternak yang digembalakan pada padang penggembalaan memberikan kesempatan ternak untuk memilih dan mengambil sendiri hijauan yang dimakannya. Dengan demikian jika pastura baik maka diharapkan produksi ternak akan baik pula, akan tetapi jika pastura dalam keadaan buruk, seperti kebanyakan padang rumput alam maka produksi ternak juga menurun serta ada kemungkinan ternak mengkonsumsi hijauan beracun yang dapat mengganggu proses fisiologis. Berdasarkan hasil pengamatan hijauan/ leguminosa lokal yang diperoleh dengan hasil identifikasi masing-masing tanaman sebagai pada Tabel 1.

Secara alamiah, kangkungan ditemukan di kolam, rawa, sawah dan tegalan. Tumbuhnya menjalar dengan banyak percabangan. Sistem perakarannya tunggang dengan cabang-cabang akar yang menyebar ke berbagai penjuru. Tangkai daun melekat pada buku-buku batang dan bentuk helaiannya seperti hati. Bunganya menyerupai terompet. Bentuk buahnya bulat telur dan di dalamnya berisi 3 butir biji (Santoso 2008). Selain itu, tanaman kangkungan berkhasiat sebagai anti inflamasi, diuretik dan hemostatik (Maryani 2003). Tanaman kangkungan juga merupakan tanaman yang mampu menyerap logam berat atau disebut juga tanaman fitoremediator (Liong et al. 2009). Ditambahkan oleh Aiyen (2004) bahwa tanaman kangkungan mampu mengakumulasi minimum 1000 ppm $\mathrm{Pb}$.

Sementara Kiti-kiti Balanda (sebutan Bahasa Makassar), orang Jawa menyebutnya Ketepeng merupakan tanaman perdu, tingginya mencapai $5 \mathrm{~m}$, daunnya kecil dan banyak tumbuh di daerah tropis. Jonga-jonga (Dokar) merupakan pohon kecil, tumbuhan dengan banyak kegunaan ini diduga berasal dari Amerika Tengah. Namun sekarang telah tersebar ke berbagai daerah tropis dan subtropis. Dokar memiliki wujud berupa pohon berkayu lunak dan berumur panjang. Tingginya dapat mencapai $5 \mathrm{~m}$ bahkan lebih. Akarnya berbintil-bintil yang gunanya untuk fiksasi $\mathrm{N}$ sehingga dapat menyuburkan tanah. 
Bunganya besar dan keluar dari ketiak daun, bunganya apabila ada yang mekar berwarna putih. Kedua hijauan ini memiliki bau yang sangat tajam.

Table 1. Hasil identifikasi tanaman pakan ternak yang diamati

\begin{tabular}{|c|c|}
\hline Nama lokal & Klasifikasi \\
\hline \multirow[t]{8}{*}{ Kangkungan darat } & Kerajaan: Plantae (tumbuhan) \\
\hline & Divisi: Spermatophyta (menghasilkan biji) \\
\hline & Sub divisi: Angiospermae \\
\hline & Kelas: Magnoliopsida (berkeping dua/dikotil) \\
\hline & Ordo: Solanales \\
\hline & Famili: Convolvulaceae (suku kangkung-kangkungan) \\
\hline & Genus: Ipomea \\
\hline & Spesies: Ipomea reptan Poir \\
\hline \multirow[t]{8}{*}{ Kiti-kiti Balanda (kacangan liar) } & Kerajaan: Plantae (tumbuhan) \\
\hline & Divisi: Spermatophyta (menghasilkan biji) \\
\hline & Sub divisi: Angiospermae \\
\hline & Kelas: Dicotyledonae \\
\hline & Ordo: Fabales \\
\hline & Famili: Fabaceae (suku polong-polongan) \\
\hline & Genus: Cassia \\
\hline & Spesies: Cassia alata $\mathrm{L}$ \\
\hline \multirow[t]{8}{*}{ Jonga-jonga (Dokar) } & Kerajaan: Plantae (tumbuhan) \\
\hline & Divisi: Spermatophyta (menghasilkan biji) \\
\hline & Sub divisi: Angiospermae \\
\hline & Kelas: Asterids \\
\hline & Ordo: Asterales \\
\hline & Famili: Asteraceae \\
\hline & Genus: Chromolaena \\
\hline & Spesies: Chromolaena odorata \\
\hline
\end{tabular}

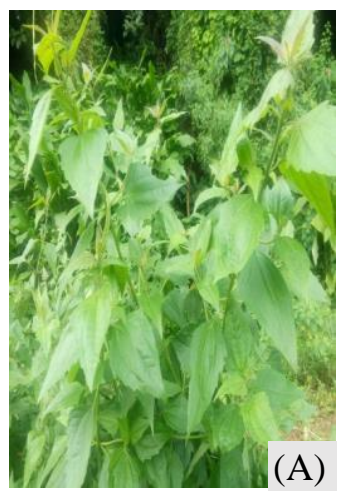

(A) Kangkungan darat
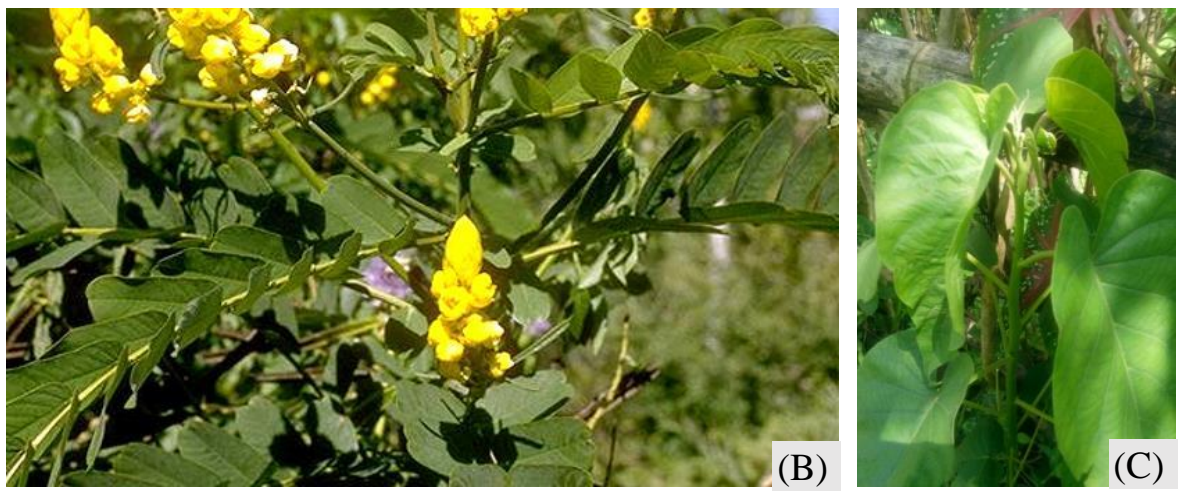

(B): Kiti-kiti Balanda

(C) Jonga-jonga/Dokar

Gambar 1. Hijauan pakan lokal, 
Table 2. Karakteristik tanaman hijauan lokal yang diamati

\begin{tabular}{ll}
\hline \hline Nama lokal & \multicolumn{1}{c}{ Hasil identifikasi } \\
\hline Kangkungan darat & Batang: berbentuk bulat dan mengeras seiring bertambahnya umur \\
& kangkungan, memiliki percabangan yang banyak \\
& Daun: bentuk daun umumnya tumpul dengan permukaan bagian \\
atas berwarna hijau tua dan bagian bawah berwarna hijau muda & Bunga: berbentuk terompet berwarna ungu/lembayung \\
& Buah: berbentuk bulat telur di dalamnya mengandung tiga butir biji \\
& Batang: Batang tanaman berkayu, berbentuk bulat, simpodial, \\
& berwarna cokelat kotor \\
Kiti-kiti Balanda & Daun: merupakan daun majemuk, menyirip genap, anak daun \\
(kacangan liar) & berjumlah antara 8-24 pasang. Pertulangan daun menyirip, tangkai \\
& pendek dan warna daun hijau. \\
& Bunga: merupakan bunga majemuk, berbentuk tandan. Mahkota \\
& bunga berbentuk kupu-kupu, berwarna kuning \\
& Buah: berbentuk polong kecil yang panjangnya bisa mencapai 15 \\
cm berwarna hijau apabila sudah tua berwarna coklat. Buah \\
mengandung biji sampai enam biji per polong \\
Batang: berbentuk kayu dan mengeras seiring bertambahnya umur \\
dengan sistem perakaran yang kuat dengan tinggi batang \\
mencapai100-150 cm \\
Daun: bentuk oval bergerigi jarang dengan ujung daun cenderung \\
runcing berwarna hijau muda \\
Bunga: berbentuk anting berkelompok berwarna ungu/lembayung \\
dan putih \\
Buah: mengandung biji banyak dan mudah tersebar oleh angin \\
\hline
\end{tabular}

Sumber: Data primer (2016)

\section{Kandungan nutrisi hijauan pakan lokal}

Beberapa jenis hijauan dapat dijadikan alternatif pilihan bagi peternak untuk menjamin ketersediaan hijauan pakan ternak baik dari segi kuantitas maupun segi kualitas yang tinggi melalui analisis proksimat dan zat antrinutrisi yang terkandung di dalamnya. Berikut pada Tabel 3 dan 4 disajikan hasil analisis proksimat dan kadar antinutrisi pakan.

Tabel 3. Kandungan nutrisi hijauan pakan lokal

\begin{tabular}{lccc}
\hline \hline & \multicolumn{3}{c}{ Jenis hijauan lokal } \\
\cline { 2 - 4 } Komposisi kimia (\%) & Kangkungan & $\begin{array}{c}\text { Kiti-kiti Balanda } \\
\text { (kacangan liar) }\end{array}$ & Jonga-jonga (Dokar) \\
\hline Kadar air (KA) & 7,86 & 8,13 & 8,86 \\
Abu & 10,37 & 11,52 & 7,63 \\
Protein kasar (PK) & 21,36 & 24,55 & 22,63 \\
Lemak kasar (LK) & 3,30 & 3,13 & 6,38 \\
Serat kasar (SK) & 12,81 & 15,62 & 9,81 \\
Energi (kkal/kg) & - & - & $3.583,50^{*}$ \\
\hline
\end{tabular}

Sumber: Hasil analisis Laboratorium Dinas Peternakan dan Kesehatan Hewan Provinsi Sulawesi Selatan (2016); *Hasil analisis Loka Penelitian Kambing Potong Sei Putih 
Kualitas dari hijauan dicerminkan dari nilai nutrisi yang terkandung di dalamnya. Hijauan mengandung protein kasar, lemak, serat kasar, bahan ekstrak tanpa nitrogen dan mineral. Protein kasar merupakan nutrisi yang sangat penting bagi ternak. Hijauan yang mengandung protein kasar yang tinggi dimiliki oleh sebagian besar leguminosa. Berdasarkan hasil analisis proksimat tampak bahwa ketiga hijauan tersebut memiliki PK $>20 \%$ dan SK <18\% sehingga dikatakan bahwa hijauan tersebut merupakan sumber protein. Kandungan protein yang tinggi pada hijauan liar dapat dijadikan alternatif pakan ternak terutama di musim kemarau mengingat jumlahnya melimpah ketika musim kemarau. Pemanfaatan hijauan sebagai bahan pakan merupakan salah satu usaha untuk mencari sumber pakan alternatif yang mudah didapat dan tidak bersaing dengan kebutuhan manusia. Ditambahkan oleh Sagala (2009) bahwa, tepung daun Jonga-jonga dapat digunakan sebagai pakan burung puyuh sampai pada level $10 \%$ dalam ransum. Sementara berdasarkan hasil penelitian Ginting (2009) menyatakan bahwa pengaruh Jonga-jonga (Chromolaena odorata) dalam ransum ayam pedaging memberikan pengaruh tidak nyata terhadap konsumsi ransum dan konversi ransum hingga level $10 \%$.

\section{Kandungan anti nutrisi hijauan pakan lokal}

Meskipun ketiga hijauan tersebut mengandung protein kasar yang cukup tinggi yang hampir menyamai protein bungkil kelapa, akan tetapi pemanfaatannya sebagai pakan ternak dibatasi oleh tingginya kandungan Hydro Cyanic Acid $(\mathrm{HCN})$ yang terkandung di dalamnya. Adanya senyawa HCN dalam bahan pakan dapat menjadi pembatas dalam pemanfaatannya, karena senyawa antinutrisi ini dapat menimbulkan pengaruh yang negatif terhadap pertumbuhan dan produksi namun tergantung dosis yang masuk ke dalam tubuh ternak. Oleh karena itu, hijauan tersebut harus diolah terlebih dahulu sebelum diberikan kepada ternak untuk menurunkan atau menginaktifkan senyawa ini,

Secara umum keracunan HCN atau sering disebut juga prusic acid, asam prusik atau asam sianida pada ternak tergantung pada kadar HCN dalam pakan ternak, jumlah pakan yang dikonsumsi, dan kondisi ternaknya. Kandungan asam sianida yang lebih dari 500 ppm, sudah perlu diwaspadai. Sementara itu, level toksik HCN pada sapi dan kerbau 2,2 $\mathrm{mg} / \mathrm{kg}$ bobot badan, sedangkan pada kambing dan domba $2,4 \mathrm{mg} / \mathrm{kg}$ bobot badan. Pada ketiga hijauan lokal di atas memiliki kadar $\mathrm{HCN}<500$ ppm sehingga dikatakan aman untuk dikonsumsi ternak.

Selain itu, zat antinutrisi lainnya adalah tanin. Tanin yang terkandung dalam hijauan dapat menimbulkan penurunan palatabilitas dan pencernaan protein. Kadar tanin 0,3\% dalam pakan ternak sudah dapat menimbulkan gangguan tersebut. Dari ketiga hijauan lokal yang memiliki kadar tanin di atas 0,3\% adalah Kiti-kiti Balanda (kacangan liar), sehingga penggunaannya sebagai pakan ternak harus dibatasi. Menurut Ikhimioya (2003), Jonga-jonga (Chromolaena odorata) mengandung zat antinutrisi Haemagglutinin 9,72 $\mathrm{mg} / \mathrm{g}$, Oxalate 1,89\%, Phytic acid 1,34\% dan Saponin 0,50\%.

Tabel 4. Kandungan zat antinutrisi hijauan lokal

\begin{tabular}{lcccc}
\hline \hline \multirow{2}{*}{$\begin{array}{l}\text { Komposisi kimia } \\
(\mathrm{ppm})\end{array}$} & Kangkungan & $\begin{array}{c}\text { Kiti-kiti Balanda } \\
\text { (kacangan liar) }\end{array}$ & $\begin{array}{c}\text { Jonga-jonga } \\
\text { (Dokar) }\end{array}$ & Batas aman \\
\cline { 2 - 4 } & 15,907 & 18,830 & 18,917 & $>500$ \\
HCN $(\mathrm{ppm})$ & 0,063 & 0,389 & 0,169 & $<0,3$ \\
\hline
\end{tabular}

Sumber: Hasil analisis Laboratorium Kimia Makanan Ternak Universitas Hasanuddin (2016) 


\section{Daya palatabilitas ternak}

Berdasarkan pengamatan terhadap daya suka ternak/palatabilitas selama seminggu diperoleh hasil sebagai berikut:

Tabel 5. Uji palatabilitas ternak terhadap hijauan lokal

\begin{tabular}{llcl}
\hline \hline Hari ke- & \multicolumn{1}{c}{ Jenis hijauan } & $\begin{array}{c}\text { Pakan tambahan } \\
\text { (konsentrat) }\end{array}$ & \multicolumn{1}{c}{ Keterangan } \\
\hline 1 & Kiti-kiti Balanda $1 \mathrm{~kg}$ & - & Tidak dimakan \\
& Jonga-jonga $1 \mathrm{~kg}$ & - & Tidak dimakan \\
2 & Kiti-kiti Balanda $1 \mathrm{~kg}$ & $1 \mathrm{~kg}$ & Dimakan \\
& Jonga-jonga $1 \mathrm{~kg}$ & $1 \mathrm{~kg}$ & Tidak dimakan \\
3 & Kiti-kiti Balanda $2 \mathrm{~kg}$ & $1 \mathrm{~kg}$ & Tidak dimakan \\
& Jonga-jonga 2 kg & $1 \mathrm{~kg}$ & Tidak dimakan \\
4 & Kiti-kiti Balanda $2 \mathrm{~kg}$ & $2 \mathrm{~kg}$ & Dimakan \\
& Jonga-jonga 2 kg & $2 \mathrm{~kg}$ & Tidak dimakan \\
5 & Kiti-kiti Balanda $1 \mathrm{~kg}$ & $2 \mathrm{~kg}$ & Dimakan \\
& Jonga-jonga $1 \mathrm{~kg}$ & $2 \mathrm{~kg}$ & Dimakan \\
6 & Kiti-kiti Balanda $1 \mathrm{~kg}$ & $2 \mathrm{~kg}$ & Dimakan \\
& Jonga-jonga $1 \mathrm{~kg}$ & $2 \mathrm{~kg}$ & Dimakan \\
\hline
\end{tabular}

Sumber: Data Primer UPTD Pembibitan HMT (2016)

Pemberian pakan untuk ternak harus memperhatikan kecukupan nutrisi yang dibutuhkan, terlebih dari unsur hijauan. Jika kualitas hijauan yang diberikan masih rendah, maka harus diberikan pakan tambahan (pakan penguat) untuk mencukupi kebutuhan nutrisinya. Berdasarkan hasil uji palatabilitas tampak bahwa hijauan lokal kurang palatabel jika diberikan sebagai pakan tunggal. Pemberian pakan tambahan seperti konsentrat mampu meningkatkan palatabilitasnya. Kombinasi pemberian pada hari kelima dan keenam menunjukkan palatabilitas yang terbaik. Rendahnya tingkat palatabilitas disebabkan hijauan ini memiliki bau yang sangat tajam sehingga kurang disukai ternak. Oleh karena itu, sebelum diberikan kepada ternak, hijauan tersebut harus dikeringkan.

\section{KESIMPULAN}

Rendahnya produktivitas hijauan membuka peluang bagi introduksi hijauan lokal agar kebutuhan pakan ternak ruminansia yang dikembangkan dapat terpenuhi. Ditemukan tiga macam hijauan pakan lokal yang dapat dijadikan sebagai alternatif pakan ternak yaitu Kangkungan Darat, Kiti-kiti Balanda dan Jonga-jonga dengan kandungan PK >20\%, SK $<18 \%$, HCN $15-19 \%$ dan tanin 0,06-0,389\%. Pemberian sebagai pakan ternak perlu dikombinasikan dengan pakan penguat guna meningkatkan palatabilitas.

\section{DAFTAR PUSTAKA}

Aiyen. 2004. Importance of root growth parameters to $\mathrm{Cd}$ and $\mathrm{Zn}$ acquisition by nonhyperaccumulator and hyperaccumulator plants [Dissertation]. Stuttgart (Germany): University of Hohenhein, Institutebof Plants Nutrition, Verlag Graner- Meuren-Stuttgart. 
Badan Ketahanan Pangan Nasional. 2010. Penyusutan luas lahan tanaman pangan perlu diwaspadai [Internet]. [cited 29 Maret 2017]. Available from: http://www.setneg.go.id/index.php?option= com_content\&task=view\&id=4617.

Ginting J. 2009. Pengaruh semak Bunga Putih (Chromolaena odorata) dalam ransum terhadap performans ayam pedaging umur DOC-42 hari [Skripsi]. Medan (Indonesia): USU.

Haryanto B. 2004. Sistem integrasi padi dan ternak (SIPT) dalam program P3T [abstrak]. Disampaikan dalam: Seminar Sepekan Padi Nasional. Sukamandi, 15-19 Juli 2004. Sukamandi (Indonesia): Balai Penelitian Tanaman Padi.

Liong S, Noor A, Taba P, Zubair H. 2009. Dinamika akumulasi kadmium pada tanaman kangkung darat (Ipomoae reptans Poir). J Indonesia Chim Acta. 2:1-7.

Maryani H. 2003. Tanaman obat untuk mengatasi penyakit pada usia lanjut. Jakarta (Indonesia): Agromedia Pustaka. hlm. 20.

Nitis IM, Lana K, Sudana LB, Sutji N. 1992. Pengaruh klasifikasi wilayah terhadap komposisi botani hijauan yang diberikan pada kambing di Bali di waktu musim kemarau. Dalam: Prosiding Seminar Penelitian Peternakan. Bogor (Indonesia): Puslitbangnak.

Sagala NS. 2009. Pemanfaatan semak Bunga Putih (Chromolena odorata) terhadap pertumbuhan dan IOFC dalam ransum burung puyuh (Cortunix-cortunix japonica) umur 1 sampai 42 hari. Medan (Indonesia): USU.

Santoso HB. 2008. Ragam dan khasiat tanaman obat. Jakarta (Indonesia): Agromedia Pustaka.

\section{DISKUSI}

\section{Pertanyaan}

Berapa produktivitas hijauan, sepertinya perlu dikaji lagi kandungan antinutrisi, biasanya tidak disukai ternak karena ada sesuatu. Misalnya apabila hijauan dilayukan dan baunya sudah hilang maka ternak mau makan hijauan tersebut. Karena apabila produksi hijauan cukup mendukung maka akan diupayakan untuk mengatasi antinutrisi ini.

\section{Jawaban}

Pada cuaca ekstrem sudah dicobakan dan setelah kering palatabilitas masih kurang, yang ingin diteliti saat ini adalah kandungan hormon. Misalnya di kacang ada estrogen yang dapat menyebabkan CLP, sehingga kandungan hormon tersebut penting diteliti untuk menghindari keguguran. 